\title{
The Effect of Using the Jigsaw Cooperative Learning Technique on Saudi EFL Students' Speaking Skills
}

\author{
Hayat Rasheed Hamzah Alamri \\ Curricula \& Teaching Methods Dep., College of Education, Taibah University PO box 4532, Madinah \\ 41412, Kingdom of Saudi Arabia \\ * E-mail of the corresponding author: hayatalamri@hotmail.com
}

\begin{abstract}
This quasi-experimental study aimed to investigate the effect of the jigsaw cooperative learning (CL) technique on the performance of Saudi English as a Foreign Language (EFL) students' in speaking skills and on promoting their appropriate practice of vocabulary, accuracy, fluency and pronunciation during oral tasks. The study sample consisted of 28 female students studying at Prince Megren University. The participants were assigned in two small size language classes and randomly specified as a control group $(\mathrm{N}=13)$ and a jigsaw group $(\mathrm{N}=15)$. Data was collected through a rubric designed to assess speaking. The results of the study showed that there was statistically significant differences in terms of Saudi EFL female students' overall performance in speaking skills in favour of the jigsaw group. The results also showed that the participants in the jigsaw group outperformed those of the control group in the speaking competencies: vocabulary, accuracy, fluency, and pronunciation. The study presented some recommendations and suggestions in light of the results of the research.
\end{abstract}

Keywords: Jigsaw, Cooperative Learning, Speaking Skills

\section{Introduction}

According to Nunan (1991), speaking is the "ability to express oneself in the situation, or the activity to report acts, or situation in precise words or the ability to converse or to express a sequence of ideas fluently" (p. 23 ). Thus, the purpose of speaking is not only to communicate with others but also to obtain new information and to share ideas with others. For this reason, there are many processes involved in the production of speaking. Levelt (1993) specifies four major processes in speaking: conceptualization, formulation, articulation, and selfmonitoring. Bygate (1991) adds three other major processes: pronunciation, accuracy, and fluency, and reported that these processes happen very quickly in the mind of the speaker. Moreover, a speaker needs to be able to anticipate and then produce a correct response when speaking. As indicated by Burns and Joyce (1997), turntaking, restating, asking questions, and providing feedback are all elements that a speaker must manage in a speaking situation.

Generally, speaking skills appear to be demanding for the speakers of English as a foreign language (EFL). Many researchers (Chen \& Chang, 2009; Kao \& Craigie, 2010; Pappamihiel, 2002; Subaş1, 2010) have stated that reaching accuracy and fluency in speaking can be a challenge for EFL learners, who mostly seem reluctant to engage in any interactive tasks in speaking classrooms.

Evidently, there are factors that contribute to EFL students' deficiencies in speaking skills. According to McCroskey (1992), less exposure to language use, inappropriate methods of teaching, improper listening skills, and the lack of proper vocabulary are some of the key factors that cause such deficiencies. Based on the results of a study conducted by Jamshidnejad (2010), Iranian EFL teachers suggests more practice that may increase the level of oral communication. Moreover, as reported by Latha (2012), one of the greatest challenges that face Indian EFL learners is their inability to produce even one sentence without making grammatical errors. Latha has referred this deficiency to the students' views towards learning English language only to pass exams and not to practice it in real-life situations.

Similarly, as in many other countries, the ability to speak English fluently is a necessity in Saudi Arabia; however, Saudi EFL classrooms witness comparable problems and issues regarding deficiencies in speaking skills. Aljumah (2011) has found that unwillingness and shyness are the reasons beyond the reluctance of Saudi EFL university students to speak. Similar results were obtained by Hamouda (2013) who has referred the reluctance of Saudi EFL students to speak and share in oral activities to their low language proficiency level, 
shyness, and fear of speaking and making mistakes in front of others. As a result, Saudi EFL students seem unable to practice speaking skills in order to improve their own academic performance, increase their practice options, and enhance their language competence.

In line with recent educational movement reforms that demand to impart oral communication skills to students, teachers should implement teaching strategies and techniques that provide learners with deep knowledge and encourage them to practice speaking. In order to engage students in learning, it is suggested to use the student-centred approach such as the cooperative learning. Cooperative learning (CL), as indicated by Gillies (2016), involves forming groups that allow learners to work together to incentivize learning. Moreover, when students interact with each other during cooperative activities, they deepen their understanding, increase the quality of reasoning, and improve the accuracy of long-term retention (Bukunola \& Idowu, 2012). Introducing CL as one of the teaching methods in EFL classrooms gives students more chances to construct their own knowledge through discussion and peer tutoring. This, in turn, promotes active learning, which develops critical thinking and logical reasoning skills (ibid). Studies have revealed that students improve both academically and socially when given the opportunity to interact with each other. Altun, (2015) and Bratt (2008) argues that CL enhances students' social competence and, in particular, their ability to collaborate with peers. In two separate studies, Slavin (1980a) and (1980b) has indicated that the use of CL methods significantly increased students' performance, achievement, and self-esteem. Slavin (1983) has added that the use of group rewards and individual accountability are necessary to the effectiveness of CL methods. In his most recent study, Slavin (2014) has noticed that CL as a pedagogical practice has had a deep effect on student learning and socialization.

A variety of cooperative learning techniques have been used in diverse educational settings. Such techniques contain jigsaw, which introduces students to the logic of scientific research and develops their capacity for continuous learning. According to Richards, Platt, and Platt, "the jigsaw technique is a type of cooperative learning in which each member of a group has a piece of information that is needed to complete a group task (1992, p.87)". It provides learners with opportunities for face-to-face interaction, verbal interchanges, challenge each other's point of view, and small group skill building (Evcim \& İpek, 2013). Moreover, in the jigsaw technique, students are encouraged to listen, cooperate, and exchange their thoughts aloud.

Furthermore, researchers believe that the jigsaw CL technique may improve EFL learners' different language skills. For instance, Lin (2010) has carried out a study to discover the perspectives of Taiwanese teachers and students towards the jigsaw CL technique in English classrooms. The results of a mixed- methods show that the jigsaw CL technique significantly contributed to the learning of English by first-year university students. Although both instructors and students indicated positive and negative opinions about the jigsaw CL technique, they expressed their willingness to continue adopting it in their future English classes. Moreover, the findings of a study conducted by Mengduo and Xiaoling (2010) have indicated that the jigsaw technique promotes EFL student participation and enthusiasm effectively. As well as, it is considered a convenient technique to achieve learning tasks in the language classroom. Moreover, the results of a study carried out by Evcim and İpek (2013) have shown that the academic achievement of 48 English prep school students at Abant Izzet Baysal University is increased after implementing Jigsaw II method in learning.

Despite the several studies that have investigated the jigsaw CL technique (Aimah, 2013; Ali, 2001; Maden, 2011; Meng, 2010; Zahra, 2014), there remains a need to investigate the effect of the jigsaw CL technique on Saudi EFL students' performance in speaking skills in terms of promoting the appropriate practice of vocabulary, accuracy, fluency, and pronunciation during speaking tasks.

\section{Statement of the problem}

Speaking is considered as one of the significant aspects of teaching EFL in higher education institutions because they usually reflect the learners' abilities to use the language. However, the teaching of speaking skills in Saudi Arabia is currently not experiencing positive results. In Saudi classrooms, less attention is given to speaking skills. Hence, Saudi EFL students, as well as other EFL learners, face difficulties in achieving speaking proficiency. They may perform better in grammar, reading comprehension and sometimes writing skills, but when asked to speak up and share ideas, they remain silent, appear reluctant, or may find themselves lost and confused. Aljumah (2011) stated, "Saudi students find it inappropriate to speak in class because of their fear to be seen as verbally challenging their teachers' views openly and publicly. Even when they do, they speak a little." (p.84). 
Recently, the preparatory programme at Saudi Universities gives much attention to learning English language. As one of the four language skills, speaking is now assuming increasing importance. Likewise, female students at Al-Bayan College (now Prince Megren University) who are studying English in the prep-year programme, experience similar difficulties in speaking English. They are taught English language for passing the TOEFL exam with an acceptable score. Even though they are provided with intensive exposure to English language, they still have problems regarding communicating orally in front of their instructors or classmates. Moreover, they appear shy and reluctant to speak, and unwilling to express selves, provide comments, or even pose questions.

Hence, there is a need for a balanced instructional approach in EFL teaching that addresses and integrates the pedagogical implications of the sub-skills as well as the functional and interactional models of language. Such an approach would focus on developing the learner's linguistic as well as pragmatic competencies through the provision of classroom opportunities that allow learners to democratically and independently interact in order to construct knowledge, negotiate meaning, and enhance comprehension (Christison \& Bassano, 1981).

Consequently, the purpose of this quasi-experimental study is to investigate the effect of the jigsaw CL technique on Saudi EFL female students' performance in speaking skills in terms of promoting their appropriate practice of vocabulary, accuracy, fluency, and pronunciation during speaking tasks.

\section{Questions of the study}

The questions addressed in this study are:

1. What is the effect of the jigsaw CL technique on Saudi EFL female students' performance in speaking skills?

2. What is the effect of the jigsaw CL technique on Saudi EFL female students' appropriate practice of vocabulary, accuracy, fluency and pronunciation during speaking tasks?

\section{Statements of hypotheses}

The following null hypotheses are tested at a 0.05 level of significance:

1. H01. There is no significant difference between the mean scores of Saudi EFL students taught with the jigsaw CL technique and those taught with the conventional method regarding their performance in speaking skills.

2. H02. There is no significant difference between the mean scores of the Saudi EFL students taught with the jigsaw CL technique and those taught with the conventional method regarding the appropriate practice of the speaking competencies: vocabulary, accuracy, fluency and pronunciation.

\section{Significance of the study}

The study attempts to reflect the need for a workable strategy to help Saudi EFL undergraduate students achieve proficiency in speaking skills. Moreover, it may offer a major contribution by informing EFL teachers about the necessary procedures to implement the jigsaw CL technique in their classrooms. Therefore, the study draws the attention of university programme developers, reviewers, and evaluators to the weaknesses of Saudi EFL students' speaking skills in order to make some changes in the EFL academic programme. Moreover, they may make use of the constructive alignment approach in which the teaching methods, assessment techniques, and relevant learning activities should align with the intended learning outcomes (ILOs) (Biggs \& Tang, 2011).

\section{Literature review}

One area of research underpins the research questions and inform this paper. This area relates to the jigsaw CL technique in language teaching. The researcher provides a brief overview of the historical background of the jigsaw technique, its advantages and disadvantages, as well as, the related research that clearly investigates implementing it in language classrooms.

\subsection{Historical background of the jigsaw CL technique}

The jigsaw CL technique was first developed in 1971 by the social psychologist Elliot Aronson with his students from Texas University and the University of California. Aronson and his graduate students has noticed that the competitive atmosphere of classroom rises inter-group hostility and hypothesized that one of the causes 
of harm to students was the use of traditional methods of teaching, in which the teacher does not create an active learning environment (Aronson \& Bridgeman, 1979; Aronson, 2004, 2008). In any traditional classroom, the teacher is the sole expert who leads classroom activities without giving students chances to discover their knowledge. For this reason, Aronson aims to change this by creating the jigsaw classroom as a highly structured cooperative learning situation to promote motivation in learning, develop interpersonal skills, and increase students' achievements (Adhami \& Marzban, 2014; Hosseini et al. 2014; Parmadyani, 2013).

Like pieces of a jigsaw puzzle, students -in the original jigsaw technique- are assigned to small groups that include different skill levels. In the teaching-learning materials, each group member is responsible for becoming an "expert" on one specific part. The "expert group" members communicate with each other in order to discuss the learning material. They return to their "home group" to teach their mastered parts to other members of the teams (Parmadyani, 2013; Reese, 2009; Voyles, Bailey \& Durik, 2015). Several modifications were subsequently introduced to Jigsaw II, in which students are required to write down some notes in the provided "expert sheets" and introduce it back to the home group. Moreover, students are also assessed individually not in groups. Recently, in Jigsaw IV, several additional teacher-based features were incorporated into the technique, such as teacher introduction of the topic, quizzes for expert groups, a quick revision before submitting an individual assessment, and explaining of any part that not fully discussed in the jigsaw classroom (Mengduo \& Xiaoling, 2010).

\subsection{Advantages and disadvantages of the jigsaw CL technique}

The results of an early study by Aronson and Bridgeman (1979) have indicated that such structured interdependence increases the self-esteem, interpersonal attraction, and academic performance of students. The jigsaw technique encourages students to participate actively in classroom activities, enhances their motivation when working together, and develops self-esteem while sharing ideas.

Based on the results of Perkins and Saris (2001), students have reported that jigsaw CL technique extends their understanding of content, uses class time effectively, and provides diverse learning experiences. According to Aronson (2004), the jigsaw CL technique develops individual and group responsibility, as well as, encourages collaboration across groups. Similarly, Reese (2009) describes learners in the jigsaw cooperative classroom as diverse individuals who display remarkable abilities to benefit from this cooperative structure. In addition to developing teamwork skills and increasing the depth of knowledge, Mengduo and Xiaoling (2010) have ascertained that the jigsaw classroom also decreases learners' anxious feelings and instills self-esteem and selfconfidence. As indicated by Parmadyani (2013), the jigsaw technique provides a natural system in which students are capable of showing individual responsibility, leading interaction, and using discussion skills across groups. Similarly, Astane and Berimani (2014) have added that one of the primary advantages of the jigsaw method is that it creates a kind of team atmosphere among the groups, which is more acceptable to peers. Zahra (2014) have concluded four benefits of the jigsaw technique. First, it allows students to form diverse groups including different races and cultures to achieve specific academic goals. Second, it offers an extremely interactive learning experiences and activities. Third, it develops learners' higher thinking skills of analysis, synthesis, and evaluation. Fourth, it provides students with chances to design their presentations and form certain questions that enhance motivation and help to complete the required tasks. Generally, good planning of the jigsaw CL technique might lead to its appreciation by students and create a preferable learning setting.

Although the jigsaw CL technique appears to be beneficial, it has been found not be sufficiently effective for some students. Reese (2009) has referred to some potential problems of the jigsaw method, such as involving different levels of students in one group may make it difficult for slower students and boring for high achievers. Astane and Berimani (2014) have added that some students doubted the validity and sufficiency of the information received from their peers to answer examination questions. Moreover, some students felt insecure with the teacher being just a facilitator or merely spending class time in monitoring and guiding group discussion.

\subsection{Jigsaw CL technique in EFL classroom}

In the EFL context, numerous studies have highlighted the importance of the jigsaw CL technique to improve a specific language skill. The majority of the reviewed studies have reported effects on students' performance in different language skills. Notably, the developments came from the implementation of jigsaw CL technique. Regarding reading skills, Ali (2001) has explored the effect of using the jigsaw technique on Egyptian pre-service EFL teachers reading comprehension and anxiety. Data has been collected through using the TOEFL reading comprehension section and a Foreign Language Reading Anxiety Scale (FLRAS). The findings of the 
study showed the use of the jigsaw reading technique reduced foreign language reading anxiety and increased the reading comprehension of the jigsaw group subjects. In line with the previous findings, Meng (2010) has combined jigsaw CL with the teaching of English reading. The results have confirmed that jigsaw CL technique is more effective for teaching English reading at college level. In a quasi-experimental study carried out by Adhami and Marzban (2014) to investigate reading ability, the results of the posttest have revealed that female Iranian intermediate high school EFL learners who assigned to the jigsaw group did much better than those in the control group.

However, Maden (2011) has identified that the Turkish student teacher candidates might not have found the jigsaw CL technique to be effective in terms of academic achievement in written expression. The results obtained from the Success Test for Written Expression (STWE) revealed that there was no significant variation between the jigsaw group and the control group in teaching written expression. On the contrary, in a quasiexperimental study conducted by Hosseini, Maleki, and Mehrizi (2014), the results have reported that the Iranian EFL learners who were taught writing using the Jigsaw II technique performed better than the non-jigsaw group. In a quasi-experimental study, Zahra (2014) has investigated the improvement in EFL students' ability to write a descriptive text using the jigsaw technique. The results of the independent t-test showed that the jigsaw technique improved the tenth-grade high school students' ability to write a descriptive text.

With respect to speaking skills, Wang (2009) has explored the effect of using the jigsaw CL technique on conversational skills. A sample of college students has been directed to listen carefully for a sequence, gist, and details in order to practice conversation, before creating dialogues from the Soundwaves Book to model an authentic situation. After a frequent exposure to three exercises in small groups, students have been tested in their linguistic and conversational competence. The results have identified that the students had experienced learning motivation to listen and speak and to use interpersonal relations and collaborative work to achieve a common goal. In his classroom research, Aimah (2013) has examined the improvement in students' speaking ability through Jigsaw and Numbered Heads Together (NHT) techniques. Data has been collected through speaking tests, observation notes, and a questionnaire. The results show that the EFL students' speaking ability improved significantly. As well, students were more enthusiastic about joining the class and were able to learn the material and convey it to others effectively. They also have expressed gaining confident to speak up without any pressure. The result of the questionnaire has indicated that more than $75 \%$ of the EFL students have expressed their agreement on the benefits of the application of Jigsaw and NHT techniques to speaking skills.

\section{Research methodology}

This study adopted a quasi-experimental design to draw cause-and-effect conclusions among the research variables. It aims to investigate the effects of the jigsaw CL technique treatments that was administered to the experimental but withheld from the control group.

\subsection{Participants}

The sample of this study was drawn from Al Bayan College (which recently became Prince Megren University) in Saudi Arabia. The total sample of 28 EFL female students was enrolled in the preparatory year language programme. They were selected to participate in the research treatment during the second semester of the academic year. Research participants were conveniently selected for the experimental $(\mathrm{n}=15)$ and the control $(n=13)$ groups. A five-week treatment period was provided for both groups. In order to control any possible confounding variables, the researcher ensured that the participants had not previously studied any unit included in the research treatment period. All participants were similar in age (21), speaking class hours (20), and class timing (two hours). The research sample was given background information regarding the study prior to obtaining their consent and the EFL teacher provided necessary instructions for the experimental group.

\subsection{Instrument}

The data were collected using a quantitative method. Both groups spent a total of 20 hours in class over a period of five weeks during the research treatment period. In order to investigate the effect of the jigsaw CL technique on Saudi EFL female students' speaking performance, a five-dimension speaking skill rubric was used. It consisted of vocabulary that aims to categorize EFL students' practice of vocabulary during the speaking tasks, and their accuracy and ability to speak using very formal language (Allen \& Waugh, 1986). Furthermore, it examined fluency in order to categorize EFL students' levels of interaction during communication (Richards, 2006) and pronunciation, in order to categorize EFL students' production of significant sounds (Dalton \& 
Seidlhofer, 2001).

The speaking skill rubric used to assess each competence clearly identified the range of responses that create various degrees of competence appropriate for the developmental level of the Saudi EFL students (see Appendix A).

As a group of native speaker experts in the preparatory year language programme developed the speaking skill rubric, the researcher checked the clarity of the research instrument by computing its reliability coefficients. The sample for the pilot study was selected randomly from the results of two language classes in the first semester of the academic year. The results indicated that the Cronbach's alpha coefficient value of the speaking skill rubric was $(0.928)$ for the first class ( $\mathrm{n}=25$ students), and ( 0.953$)$ for the second class ( $\mathrm{n}=23$ students), with an average Cronbach's alpha coefficient value ( 0.941$)$ for both classes ( $\mathrm{n}=48$ students).

\subsection{Procedure}

Classroom teacher's preparation. It was quite easy to discuss the steps of the intervention with the native speaker teacher, who cooperated and allowed the researcher to implement the jigsaw CL technique in one of her classes.

EFL students' preparation. Prior to the research treatment period, the female EFL students in the experimental group were familiarized with the jigsaw CL technique, encouraged to practice their new roles as peer tutors, and trained to master particular relevant skills, such as searching for more information, discussing ideas with peers, taking notes, and questioning peers on important information.

Curriculum and speaking materials. The preparatory year language programme uses the New Headway Plus as a 12-unit course book. It focuses on grammar, a clear vocabulary syllabus, real-world speaking skills using everyday spoken English, and a balanced, integrated-skills syllabus. The implementation of the jigsaw CL technique covered five units (6-10) during a period of five weeks.

Groups. For the purpose of the study, two groups were formed: the experimental group adopted the jigsaw CL technique and the control group was taught traditionally. The two groups were introduced to the same speaking lessons within the same number of speaking classes.

The experimental group. The researcher used the jigsaw CL technique and divided the experimental class into three groups (A, B and C). Each group consisted of five students with different speaking skill levels based on their previous speaking assessments results.

The control group. The students in the control class were taught traditionally the same topics and for the same length of time. Moreover, some discussion and class activities were implemented as often as those in the experimental class. The procedure was that the teacher presented each speaking topic to the students with some detailed information and directed them to discuss the details. The students were usually given the opportunity to ask questions about points they did not understand, and short summaries were made available from the teacher after each speaking topic. Finally, the students participated in some oral assessment activities. The teacher corrected their mistakes carefully, gave detailed feedback, and praised those who participated well in the speaking tasks.

Treatment. The following steps were used for implementing the jigsaw CL technique class:

Step 1: Topic distribution: The teacher assigned the speaking materials for each speaking class and divided each speaking topic into five parts; each member of the home or jigsaw group was told in advance about a different part of the speaking class topic and was assigned responsibility for it. Each jigsaw group member was given a printed sheet containing guided questions or instructions asking her to search for some key information and knowledge. To encourage cooperation rather than competition, the students were encouraged to cooperate in collecting information through reading, research and discussion outside the classroom regarding their parts of the speaking topic.

Step 2: Expert groups: Each expert group was required to have a leader, who was chosen in terms of her ability level to handle the tasks. During the first 30 minutes of each class, each member of the jigsaw group was required to join other members assigned to the same segment or part to form temporary expert groups. The expert group members were guided to address questions and discuss the main points of the specific segment or part, and to lead their peers to review their allotted material with other "experts".

Step 3: Jigsaw groups: During the next 60 minutes of class time, the students were instructed to join their particular jigsaw groups so that they could teach the concepts to each other. Students were directed to take turns 
clarifying the concepts they had been covered. Likewise, the other students were told to propose questions to enable as much knowledge as possible to be shared during the allocated time.

Step 4: Teacher's monitoring: Usually, the group leader handled the tasks, except if any group (expert or jigsaw) was experiencing trouble, in which case the teacher would make an appropriate intervention. The teacher also observed the learners and took some notes for each class.

Step 5: Class discussion: In the last 30 minutes of class, the jigsaw groups shared the results of their experience with other classmates in the class and the teacher commented on the cooperative speaking class. The entire class participated in some oral activities regarding the concepts covered.

Step 6: Assessment: Based on the nature of speaking skills as an interactive and social process, the assessment was delivered by a trained assessor, who was a native speaker teacher. She received sufficient training from the professionals of the prep-year English programme to make her assessment consistent. The speaking assessment sessions were held weekly at the end of each topic and in a one-to-many setting (namely an oral presentation). The assessments of speaking skill included an assessment of vocabulary, accuracy, fluency, and pronunciation. Every student was allocated 10 minutes to give an oral presentation in front of their peers and the trained assessor followed the criteria regarding the competencies in order to assess performance. In this situation, the EFL female students in both groups were assessed five times for the five topics.

\section{Data analysis}

The data collected were analyzed using SPSS version 21. The independent samples t-test was conducted to compare the mean scores between the jigsaw and control groups regarding speaking skill.

\section{Findings}

The results of the independent-samples t-test were used to answer the research questions and test the null hypotheses. Table 1 represents the results of the overall speaking performance and the speaking competencies: vocabulary, accuracy, fluency, and pronunciation.

Table 1: Results of independent sample T- test

\begin{tabular}{|c|c|c|c|c|c|c|c|}
\hline \multirow{2}{*}{$\begin{array}{c}\text { Speaking } \\
\text { Competencies }\end{array}$} & \multicolumn{7}{|c|}{$(\mathrm{n}=$ Jigsaw group $=15 ;$ Control group $=13)$} \\
\hline & Groups & Mean & $\begin{array}{c}\text { Std. } \\
\text { Deviation }\end{array}$ & $\mathrm{t}$ & df & $\begin{array}{l}\text { Sig. (2- } \\
\text { tailed) }\end{array}$ & $\begin{array}{l}\text { Eta } \\
\text { square }\end{array}$ \\
\hline \multirow{2}{*}{$\begin{array}{c}\text { Overall speaking } \\
\text { performance }\end{array}$} & Jigsaw group & 61.80 & 9.50 & \multirow{2}{*}{2.260} & \multirow{2}{*}{26} & \multirow{2}{*}{.032} & \multirow{2}{*}{0.16} \\
\hline & Control group & 51.54 & 14.34 & & & & \\
\hline \multirow{2}{*}{ Vocabulary } & Jigsaw group & 17.33 & 2.26 & \multirow{2}{*}{2.275} & \multirow{2}{*}{26} & \multirow{2}{*}{.031} & \multirow{2}{*}{0.17} \\
\hline & Control group & 14.62 & 3.95 & & & & \\
\hline \multirow{2}{*}{ Accuracy } & Jigsaw group & 16.07 & 3.01 & \multirow{2}{*}{2.315} & \multirow{2}{*}{26} & \multirow{2}{*}{.029} & \multirow{2}{*}{0.17} \\
\hline & Control group & 13.15 & 3.65 & & & & \\
\hline \multirow{2}{*}{ Fluency } & Jigsaw group & 15.07 & 2.09 & \multirow{2}{*}{3.010} & \multirow{2}{*}{26} & \multirow{2}{*}{.006} & \multirow{2}{*}{0.26} \\
\hline & Control group & 11.77 & 3.61 & & & & \\
\hline \multirow{2}{*}{ Pronunciation } & Jigsaw group & 14.73 & 2.99 & \multirow{2}{*}{2.171} & \multirow{2}{*}{26} & \multirow{2}{*}{.039} & \multirow{2}{*}{0.15} \\
\hline & Control group & 12.00 & 3.67 & & & & \\
\hline
\end{tabular}

As shown in Table (1), there was a significant difference between the scores for the jigsaw group $(\mathrm{M}=61.80, \mathrm{SD}=9.50)$ and the control group $(\mathrm{M}=51.54, \mathrm{SD}=14.34)$ regarding overall speaking performance; $\mathrm{t}$ $(26)=2.260, p<.032 ; d=0.16$. This result suggests that the jigsaw CL technique indicated a very large effect size on the overall speaking performance of Saudi EFL female students. Specifically, the results reflected a strong relationship between the use of the jigsaw CL technique and the Saudi EFL female students' performance in speaking skills. Consequently, the first research null research hypothesis (H01) was rejected.

Moreover, the results showed that there was a significant difference in the scores for the jigsaw group $(\mathrm{M}=17.33, \mathrm{SD}=2.26)$ and the control group $(\mathrm{M}=14.62, \mathrm{SD}=3.95)$ regarding vocabulary as a speaking competence; $\mathrm{t}(26)=2.275, \mathrm{p}<.031 ; \mathrm{d}=0.17$. This result suggests that the jigsaw CL technique had a significant 
effect on the vocabulary competence of Saudi EFL female students. Regarding accuracy in speaking competence, the results showed that there was a significant difference between the scores for the jigsaw group ( $M=16.07$, $\mathrm{SD}=3.01)$ and the control group $(\mathrm{M}=13.15, \mathrm{SD}=3.65) ; \mathrm{t}(26)=2.315, \mathrm{p}<.029 ; \mathrm{d}=0.17$. This results indicated that the jigsaw CL technique has an effect on accuracy competence of Saudi EFL female students.

Furthermore, there was a significant difference between the scores for the jigsaw group ( $M=15.07$, $\mathrm{SD}=2.09)$ and the control group $(\mathrm{M}=11.77, \mathrm{SD}=3.61)$ regarding fluency competence; $\mathrm{t}(26)=3.010, \mathrm{p}<.006 ; \mathrm{d}=$ 0.26 . Likewise, the results showed there was a significant difference between the scores for the jigsaw group $(\mathrm{M}=14.73, \mathrm{SD}=2.99)$ and the control group $(\mathrm{M}=12.00, \mathrm{SD}=3.67)$ regarding pronunciation competence; $\mathrm{t}(26)=$ $2.171, \mathrm{p}<.039 ; \mathrm{d}=0.15$. These results suggest that the jigsaw CL technique had a substantial effect on the fluency and pronunciation competencies of Saudi EFL female students.

Specifically, the results indicated that the use of the jigsaw CL technique increased Saudi EFL female students' speaking competencies: vocabulary, fluency, and pronunciation. Likewise, the second research null research hypothesis (H02) was rejected.

Table 2: The average scores of weekly speaking quizzes

\begin{tabular}{|c|c|c|c|c|c|}
\hline $\begin{array}{c}\text { Weekly } \\
\text { Assessments }\end{array}$ & Groups & Vocabulary & Accuracy & Fluency & Pronunciation \\
\hline \multirow{2}{*}{ First Assessment } & Jigsaw Group & 2.40 & 2.60 & 2.73 & 2.87 \\
\cline { 2 - 5 } & Control Group & 3.31 & 2.92 & 2.69 & 2.77 \\
\hline \multirow{2}{*}{$\begin{array}{c}\text { Second } \\
\text { Assessment }\end{array}$} & Jigsaw Group & 2.73 & 2.53 & 2.87 & 3.13 \\
\cline { 2 - 5 } $\begin{array}{c}\text { Third } \\
\text { Assessment }\end{array}$ & Control Group & 2.85 & 2.54 & 2.31 & 2.31 \\
\cline { 2 - 5 } & Jigsaw Group & 3.07 & 2.80 & 3.33 & 3.27 \\
\hline \multirow{2}{*}{$\begin{array}{c}\text { Fourth } \\
\text { Assessment }\end{array}$} & Jigsaw Group & 3.15 & 2.77 & 2.54 & 2.54 \\
\cline { 2 - 5 } Fifth Assessment & Control Group & 2.85 & 2.69 & 2.15 & 2.40 \\
\cline { 2 - 5 } & Jigsaw Group & 3.40 & 3.60 & 4.00 & 3.60 \\
\hline \multirow{2}{*}{ Control Group } & 2.46 & 2.23 & 2.08 & 2.08 \\
\hline
\end{tabular}

Table (2) provides more insights into the Saudi EFL female students' improvement in all of the five assessments of the four speaking competencies. Comparing the mean scores of both groups in each competency in the first and fifth exams, the results indicate that there were an acceptable improvement and change in the performance level in favour of the jigsaw group. The mean scores of the first assessment in vocabulary were (2.40), while this had improved by the fifth assessment (3.40).

In addition, the jigsaw participants scored (2.60) in the first assessment in accuracy and (3.60) in the fifth assessment. Their results showed an improvement in fluency, as the mean score of the first assessment was (2.73), while in the fifth it was (4.00). The mean scores of the first (2.87) and fifth (3.60) assessments in pronunciation indicated a similar acceptable improvement. Generally, the results showed a relationship between the use of the jigsaw CL technique and Saudi EFL female students' performance in speaking competencies.

\section{Discussions and reflections}

The results of the five-dimension speaking skill rubric indicated statistically significant differences in terms of students' speaking competencies between the jigsaw and control groups. The findings indicated that the jigsaw CL technique is an effective way to promote EFL students' oral performance, and it is considered a useful technique to enable Saudi EFL female learners to accomplish learning tasks in the speaking classroom.

Generally, these results seem to be consistent with other research (Perkins and Saris, 2001; Aronson, 2004; Parmadyani, 2013; and Astane \& Berimani, 2014) which found that general jigsaw CL technique might extend understanding of content, provide diverse learning experiences, encourage collaboration and interaction across groups, and create acceptable academic team atmosphere. Moreover, these results are consistent with results obtained by other existing research (Ali, 2001; Meng, 2010; Maden, 2011; Hosseini, et al., 2014; \& Zahra, 2014) which clearly reported the effect of using jigsaw CL technique to enhance language learning in different areas such as reading and writing skills.

More specifically, these results are in agreement with those obtained by Wang (2009), who reported that jigsaw students experienced increasing in learning to listen and speak, and to work collaboratively to achieve a 
common goal. Additionally, the study results are consistent with those of Lin (2010), Mengduo and Xiaoling (2010) who reported that the jigsaw technique has a vital role in supporting language learners to achieve offered learning tasks in the EFL classroom. Furthermore, the results are in agreement with the findings of Aimah (2013) that reported a significant improvement in students' abilities to speak. They also appear to be consistent with other research results (Adhami \& Marzban, 2014; Mohammadi \& Davarbina, 2015; Zahra, 2014) which indicated that the jigsaw instruction was more influential at improving EFL learners' language abilities.

Based on the teacher's implementation tactics and classroom observation, the significant results might be due to the EFL teacher's planning to give the students greater control over their learning by allowing them to be actively involved in the speaking tasks. Such a tactic left enough space for the jigsaw students to be independent and to work individually and in small groups. During the tasks, students provided effective assistance to each other in speaking by discussing and sharing thoughts to achieve the group's goals. As mentioned by Altun (2015) and Gillies (2016), the jigsaw CL technique enhanced the frequent giving and receiving of information, and increased students' ability to interact both academically and socially.

Moreover, as the treatment group had never experienced the jigsaw method, the EFL teacher implemented some introductory activities in each class in order to encourage the students, arouse their interest and increase their level of interaction. As part of the motivation strategies, the teacher monitored, assisted, and intervened if any group experienced trouble with the task. In addition, engagement in the introductory activities boosted not only motivation but also self-confidence that is considered a key role to increase speaking abilities. Being motivated, as indicated by Evcim and İpek (2013) and Fini, Zarei and Sardare (2014) performance of the jigsaw learners was evidently increased.

Another reason for the significant results might be the diversity of language proficiency levels amongst the learners in each group. Based on the EFL teacher's observation, organizing the group members in a diverse way encouraged the fluent and fast learners to keep the weaker ones active and secure to display a notable ability to participate. Based on their cooperation, it was clear that each member of the group believed in her responsibility not only for learning but also for supporting other members. However, students worked through the speaking tasks with support from the teacher and peers. This interpretation contrasts with that of Reese (2009) and Bukunola, and Idowu (2012) who argued that part of the drawbacks of jigsaw technique is the confusion caused to the students due to different levels involved in each group. Besides, some of the students are uncertain of the exchangeable roles of teachers and students during discussion.

Furthermore, the high level of consideration given to the correction of fluency, accuracy, and pronunciation during the treatment period might explain the results of the study. The EFL teacher is a firm believer in the importance of floating from one group to another in order to monitor the learning process and to gently offer any corrections needed for certain mistakes. Furthermore, the jigsaw students were encouraged to use peer-correction, especially during the expert discussion stage. Such variety of correction techniques were effective and influenced students' speaking performance.

Based on the teacher observation, the Saudi EFL female students gained somehow a greater sense of satisfaction and self-confidence when working on the speaking tasks, as indicated by Slavin (1980a \& b). They were very enthusiastic about tackling their parts and showed individual and group responsibility to transform their experiences and knowledge to the other members of both expert and home groups. Their self-confidence was reflected in the results of their weekly assessment quizzes, which indicated satisfactory improvement in all the speaking competencies.

\section{Conclusion and recommendations}

The current study was an attempt to investigate whether the jigsaw CL technique had any significant effect on Saudi EFL female students' speaking skills and on the following speaking competencies: vocabulary, accuracy, fluency, and pronunciation. The results revealed that the EFL students who were taught using the jigsaw CL technique showed better achievement in their overall speaking ability and performance than those taught using the conventional teaching method. Moreover, they achieved better in the four speaking competencies than those taught using the conventional teaching method.

Based on the research results, it is stressed that the jigsaw CL technique should be a consistent part of the EFL classroom, as it could have a number of advantages for EFL students. First, implementing the jigsaw CL technique in the EFL classroom makes it possible to create more independent language learning settings. Second, one of the purposes of innovative teaching practices is to change students from being passive towards being active in their learning. Following this trend, the jigsaw CL technique develops active learning by encouraging 
students to help each other to learn. Third, it also improves communication skills and increases active participation and interaction in the learning situations. Fourth, based on the teachers' observations, the jigsaw CL technique is considered a practical technique that can be used to increase motivation, augment self-confidence in classes, and reduce learners' anxiety about participating in classroom activities. Finally, the jigsaw CL technique has been shown to be effective in the development of speaking skills, which are generally neglected in Saudi EFL classrooms.

Additionally, EFL teachers are recommended to implement the jigsaw CL technique in order to improve the learning quality, increase students' speaking skills, satisfy academic and social needs, and reduce anxieties when communicating orally in English. In addition, it is recommended that further research to be carried out to provide Saudi EFL teachers and students with successful procedures for implementing the jigsaw CL technique to intensify students' English oral proficiency to be used in real-world situations.

\section{Limitations of the study}

The findings of the present study are applicable to Saudi EFL university students who are studying English at Al Bayan College (now Prince Megren University). EFL learners at other Saudi universities were not included in this research. Therefore, consideration should be given in generalizing the current findings beyond this population. In addition, the Saudi EFL students who took part in this study had just enrolled in the preparatory year language programme and were considered beginners, and the results may not be generalizable to students at a more advanced level. Moreover, the number of the students in this quasi-experimental was limited to 28 students in two classes because of the institution policy for forming small size language classes. In addition, the participants in this study were female students and any possible effects of the students' gender were not taken into account.

\section{Acknowledgements}

I would like to show my gratitude to Al Bayan College for giving me the chance to conduct this study into their preparatory year language programme. I am also grateful to all the EFL teachers for their help and collaboration. My gratitude goes to all the EFL students whose cooperation in this work is invaluable.

\section{References}

Adhami, M. \& Marzban, A. (2014). The effect of jigsaw task on reading ability of Iranian intermediate high school EFL. Journal of Academic and Applied Studies (Special Issue on Applied Sciences), 4(2), 13-24. doi.org/10.4304/tpls.4.2.387-394

Aimah, S. (2013, December). The application of jigsaw and numbered heads together techniques in improving students' ability in speaking skill. Paper presented at the $2^{\text {nd }}$ English Language Teaching, Literature, and Translation International Conference, Faculty of Languages \& Arts, Semarang State University, Java, Indonesia (pp. 476-481).

Ali, M. (2001). The effect of using the jigsaw reading technique on the EFL pre-service teachers' reading anxiety and comprehension. Journal of Education College, Helwan University, (3), 1-22.

Aljumah, F. (2011). Developing Saudi EFL students' oral skills: An integrative approach. English Language Teaching, 4(3), 84-89. doi.org/10.5539/elt.v4n3p84

Allen, W., \& Waugh, S. (1986). Dealing with accuracy in communicative language teaching. TESL Canada Journal, 3, 193-205. doi.org/10.18806/tesl.v3i0.1005

Altun, S. (2015). The effect of cooperative learning on students' achievement and views on the science and technology course. International Electronic Journal of Elementary Education, 7(3), 451-468.

Aronson, E. (2004). How the columbine high school tragedy could have been prevented. Journal of Individual Psychology, 60(4), 355-360.

Aronson, E. (2008). Jigsaw Classroom. Retrieved from https://www.jigsaw.org/

Aronson, E., \& Bridgeman, D. (1979). Jigsaw groups and the desegregated classroom: In pursuit of common goals. Personality and Social Psychology Bulletin, 5(4), 438-446.

doi.org/10.1177/014616727900500405

Astane, E., \& Berimani, S. (2014). The effect of jigsaw technique vs. concept map presentation mode on 
vocabulary learning of low-intermediate EFL learners. ELT Voices, 4(6), 113-123.

Biggs, J. B., \& Tang C. (2011). Teaching for quality learning at university: What the student does. UK: McGrawHill Education.

Bratt, C. (2008). The jigsaw classroom under test: No effect on intergroup relations evident. Journal of Community \& Applied Social Psychology, 18(5), 403-419. doi.org/10.1002/casp.946

Bukunola, B., \& Idowu, O. (2012). Effectiveness of cooperative learning strategies on Nigerian junior secondary students' academic achievement in basic science. British Journal of Education, Society \& Behavioural Science, 2(3), 307-325. doi.org/10.9734/bjesbs/2012/1628

Burns, A., \& Joyce, H. (1997). Focus on speaking. Macquarie University, Sydney: National Centre for English Language Teaching and Research.

Bygate, M. (1991). Speaking. Oxford: Oxford University Press.

Chen, I., \& Chang, C. (2009). Cognitive load theory: An empirical study of anxiety and task performance in language learning. Electronic Journal of Research in Educational Psychology, 7(2), 729-746.

Christison, M., \& Bassano, S. (1981). Look who's talking: A guide to the development of successful conversation groups in intermediate and advanced E.S.L. classrooms (Language Teaching Methodology series). San Francisco: Alemany Press.

Dalton, C. \& Seidlhofer, B. (1995). Pronunciation (Language Teaching: A Scheme for Teacher Education). United Kingdom: Oxford University Press.

Evcim, H., \& İpek, Ö. (2013). Effects of Jigsaw II on academic achievement in English prep classes. ProcediaSocial and Behavioral Sciences, 70, 1651-1659. doi.org/10.1016/j.sbspro.2013.01.236

Fini, A., Zarei, E., \& Sardare, M. (2014). The comparison between the effect on Jigsaw 2 and traditional teaching methods on educational achievement. Academic Journal of Psychological Studies, 3(1), 22-26.

Gillies, R. M. (2016). Cooperative learning: Review of research and practice. Australian Journal of Teacher Education, 41(3), 39-54. doi.org/10.14221/ajte.2016v41n3.3

Hamouda, A. (2013). An exploration of causes of Saudi students' reluctance to participate in the English language classroom. International Journal of English Language Learning, 1(1), 17-34.

doi.org/10.5296/ijele.v1i1.2652

Hosseini, S., Maleki, R., \& Mehrizi, A. (2014). On the impact of using Jigsaw II technique on the development of writing performance of Iranian intermediate EFL learners. International Journal of Language Learning and Applied Linguistics World (IJLLALW), 7(3), 198-215.

Jamshidnejad, A. (2010). The construction of oral problems in an EFL context: An innovative approach. Studies in Literature and Language, 1(6), 8-22. doi.org/10.3968/n

Kao, P., \& Craigie, P. (2010). Foreign language anxiety and English achievement in Taiwanese undergraduate English-major students: An empirical study. Hong Kong Journal, 61, 49-62.

Latha, B. (2012). Teaching English as a second language: Factors affecting learning speaking skills. International Journal of Engineering Research \& Technology, 1(7), 1-6.

Levelt, W. (1993). Lexical access in speech production. Netherlands: Springer Netherlands.

Lin, L. (2010). Perspectives of teachers and students toward cooperative learning jigsaw tasks in Taiwanese EFL Classrooms. (Doctoral thesis). Retrieved from http://www.proquest.com/en-US/products/dissertations/individuals.shtml.

Maden, S. (2011). Effect of jigsaw I technique on achievement in written expression skill. Educational Sciences: Theory and Practice, 11(2), 911-917.

McCroskey, C. (1992). Reliability and validity of the willingness to communicate scale Communication on Quarterly, 40(1), 16-25. doi:10.1080/01463379209369817

Meng, J. (2010). Jigsaw cooperative learning in English reading. Journal of Language Teaching and Research, 1(4), 501-504. doi:10.4304/jltr.1.4.501-504

Mengduo, Q., \& Xiaoling, J. (2010). Jigsaw Strategy as a cooperative learning technique: Focusing on the language learners. Chinese Journal of Applied Linguistics, 33(4), 113-125. 
Mohammadi, A. \& Davarbina, M. (2015).The effect of cooperative learning techniques on reading comprehension ability of Iranian EFL learners. International Journal of Education and Social Science (IJESS), 5(3), 525-531.

Nunan, D. (1991). Research methods in language learning. Cambridge: Cambridge University Press.

Pappamihiel, N. (2002). English as a second language students and English language anxiety: Issues in the mainstream classroom. National Council of Teaching of English, 36, 327-355.

Parmadyani, N. K. (2013). Improving reading comprehension through jigsaw technique of the eight grade students of SMPN 3 Bebandem in academic year 2012/2013. (Unpublished doctoral thesis). Faculty of Teacher Training and Education, Mahasaraswati Denpasar University, Denpasar.

Perkins, D. V., \& Saris, R. N. (2001). A "Jigsaw Classroom” technique for undergraduate statistics courses. Teaching of Psychology, 28(2), 111 - 113. doi.org/10.1207/s15328023top2802_09.

Reese, S. (2009). The jigsaw classroom. Retrieved from https://www.questia.com/magazine/1G1-197664704/the-jigsaw-classroom

Richards, J. (2006). Communicative language teaching today. New York: Cambridge University Press.

Richards, J., Platt, J., \& Platt, H. (1992). Longman dictionary of language teaching and applied linguistics. $\left(2^{\text {nd }}\right.$ ed.) Longman Group, UK.

Slavin, R. E. (1980a). Effects of student teams and peer tutoring on academic achievement and time on-task. The Journal of Experimental Education, 48(4), 252-258. https://doi.org/10.1037/e450142004-001

Slavin, R. E. (1980b). Cooperative learning. Review of Educational Research, 50(2), 315-342. https://doi.org/10.2307/1170149

Slavin, R. E. (1983). When does cooperative learning increase student achievement?. Psychological Bulletin, 94(3), 429-445. doi.org/10.1037//0033-2909.94.3.429

Slavin, R. E. (2014). Cooperative learning and academic achievement: Why does groupwork work? Anales De Psicologia, 30, 785-791. doi.org/10.6018/analesps.30.3.201201

Subaşı, G. (2010). What are the main sources of Turkish EFL students' anxiety in oral practice? Turkish Online Journal of Qualitative Inquiry, 1(2), 29-49. Retrieved from http://goo.gl/dW9cIp

Voyles, E., Bailey, S., \& Durik, A. (2015). New pieces of the jigsaw classroom: Increasing accountability to reduce social loafing in student group projects. The New School Psychology Bulletin, 13(1), 11-20.

Wang, T. P. (2009). Applying Slavin's cooperative learning techniques to a college EFL conversation class. The Journal of Human Resource and Adult Learning, 5(1), 112-120.

Zahra, R. (2014). The use of jigsaw technique in improving students' ability in writing a descriptive text: A quasi-experimental research at one senior high school in west Bandung. Journal of English and Education, 2(1), 64-75.

The Author is an EFL Assistant Professor in the Department of Curricula and Teaching Methods at Taibah University. She has achieved the status of Senior Fellow of the Higher Education Academy in 2016. She has a rich and long teaching experience at the University level for both undergraduate and graduate levels. She has contributed some research articles in refereed world journals and actively participated in several language conferences, workshops and symposia. 
Appendix A: The speaking skill rubric

\begin{tabular}{|c|c|c|c|c|c|}
\hline $\begin{array}{c}\text { Speaking } \\
\text { Competencies }\end{array}$ & $\begin{array}{c}\text { Excellent } \\
4 \text { Marks }\end{array}$ & $\begin{array}{l}\text { Good } \\
3 \text { Marks }\end{array}$ & $\begin{array}{l}\text { Adequate } \\
2 \text { Marks }\end{array}$ & $\begin{array}{l}\text { Fair } \\
1 \text { Mark }\end{array}$ & $\begin{array}{c}\text { Inadequate } \\
0 \text { Mark }\end{array}$ \\
\hline Vocabulary & $\begin{array}{l}\text { Vocabulary is } \\
\text { varied and used } \\
\text { correctly with } \\
\text { very little } \\
\text { repetition }\end{array}$ & $\begin{array}{l}\text { Most of the } \\
\text { vocabulary is } \\
\text { varied. There is } \\
\text { limited } \\
\text { repetition. }\end{array}$ & $\begin{array}{l}\text { Some of the } \\
\text { vocabulary is } \\
\text { varied. There is } \\
\text { some repetition. }\end{array}$ & $\begin{array}{l}\text { Very little of the } \\
\text { vocabulary is } \\
\text { varied. There is } \\
\text { a lot of } \\
\text { repetition. }\end{array}$ & $\begin{array}{l}\text { No relevant } \\
\text { vocabulary is } \\
\text { used. }\end{array}$ \\
\hline $\begin{array}{l}\text { Accuracy } \\
\text { (grammar) }\end{array}$ & $\begin{array}{l}\text { A clear majority } \\
\text { of presentation is } \\
\text { correct in } \\
\text { grammar and } \\
\text { word usage. }\end{array}$ & $\begin{array}{l}\text { Most of the } \\
\text { presentation is } \\
\text { correct in } \\
\text { grammar and } \\
\text { word usage. }\end{array}$ & $\begin{array}{l}\text { Some of the } \\
\text { presentation is } \\
\text { correct in } \\
\text { grammar and } \\
\text { word usage. }\end{array}$ & $\begin{array}{l}\text { Very little of the } \\
\text { presentation is } \\
\text { correct in } \\
\text { grammar and } \\
\text { word usage. }\end{array}$ & $\begin{array}{l}\text { The entire } \\
\text { presentation is } \\
\text { incorrect in } \\
\text { grammar and } \\
\text { word usage. }\end{array}$ \\
\hline Fluency & $\begin{array}{l}\text { A clear majority } \\
\text { of the words in } \\
\text { the presentation } \\
\text { are spoken } \\
\text { fluently and } \\
\text { correct in } \\
\text { pronunciation. }\end{array}$ & $\begin{array}{l}\text { Speech is } \\
\text { mostly fluent } \\
\text { with natural } \\
\text { pauses. }\end{array}$ & $\begin{array}{l}\text { Some long } \\
\text { pauses affect } \\
\text { fluency. }\end{array}$ & $\begin{array}{c}\text { A lot of } \\
\text { unnatural pauses } \\
\text { affect fluency. }\end{array}$ & $\begin{array}{c}\text { The student } \\
\text { remains silent } \\
\text { for most of the } \\
\text { time. }\end{array}$ \\
\hline Pronunciation & $\begin{array}{l}\text { A clear majority } \\
\text { of the words in } \\
\text { the presentation } \\
\text { are spoken with } \\
\text { correct } \\
\text { pronunciation. }\end{array}$ & $\begin{array}{l}\text { Most words are } \\
\text { pronounced } \\
\text { correctly. }\end{array}$ & $\begin{array}{l}\text { Some words are } \\
\text { pronounced } \\
\text { correctly. }\end{array}$ & $\begin{array}{l}\text { Few words are } \\
\text { pronounced } \\
\text { correctly. }\end{array}$ & $\begin{array}{l}\text { All words are } \\
\text { pronounced } \\
\text { incorrectly } \\
\text { pronounced. }\end{array}$ \\
\hline
\end{tabular}

